\title{
Invoking International Environmental Norms Through Treaty Interpretation
}

\author{
Rebecca Brown \\ Faculty of Law, University of Cambridge, Cambridge, UK \\ rrb34@cam.ac.uk
}

\begin{abstract}
This article analyses the way in which international tribunals considering treatybased disputes incorporate extraneous environmental principles through the use of interpretative mechanisms. Increasingly prominent in the international sphere, this approach allows States bringing claims under historical treaties to adopt and enforce contemporary understandings of environmental obligations. This article pursues an extensive survey of cases exhibiting this process, focusing on the interpretative techniques used; the extent to which the tribunals allowed for environmental arguments; and the basis, and use, of environmental norms. These results facilitate a comparative analysis, which concludes that tribunals' choices regarding each of these features ultimately depends on the underlying treaty's relationship with intertemporal law. This article thus provides a guide as to how States may effectively enforce environmental obligations, even absent explicit environmental enforcement mechanisms.
\end{abstract}

\section{Keywords}

international environmental law - treaty interpretation - evolutive interpretation systemic integration - dispute settlement - ICJ - international tribunals

\section{Introduction}

International environmental law is largely encapsulated in soft law instruments, while the treaties that codify it often lack effective dispute resolution 
and compensation mechanisms. ${ }^{1}$ Accordingly, for States wishing to litigate environmental issues on the international stage, the disjunct between the contemporary environmental obligations binding on States, and the treaties that provide a pathway to interstate litigation, poses a significant issue. However, methods of treaty interpretation offer a solution. Tribunals have increasingly adopted an 'evolutionary' approach to interpretation - whereby a treaty's substance is deemed capable of evolving alongside legal and factual developments ${ }^{2}$ - as a means of preventing the fragmentation of international law. ${ }^{3}$ This, in turn, facilitates the use of modern environmental norms to inform the interpretation of - and potentially re-substantiate - treaties that otherwise lack sufficient environmental obligations. The Iron Rhine arbitration provides one example of the impact such a method may have on State obligations: there, the Tribunal's use of an evolutionary approach allowed environmental norms to influence the allocation of costs pursuant to a nineteenth-century commercial agreement. ${ }^{4}$ Thus, a study modelling how States might take advantage of current judicial trends in the deployment of interpretative techniques is of great pragmatic significance, resolving issues arising from the absence of enforcement mechanisms in modern environmental treaties.

This article provides a novel analysis of the interpretative processes used by international courts and tribunals to integrate international environmental norms into treaty obligations. It presents findings drawn from a detailed study of cases in which environmental norms were invoked, focusing on the interpretative devices used, and the concomitant consideration of environmental law. More particularly, this article questions the extent to which contemporary environmental norms - ranging from approaches articulated in soft law instruments, to those deemed customary by international courts - may be imported

1 Jürgen Friedrich, International Environmental Soft Law: The Functions and Limits of Nonbinding Instruments in International Environmental Governance and Law (2013), 2-3. See also Pierre-Marie Dupuy, "Soft Law and the International Law of the Environment", 12(2) Michigan Journal of International Law (1991), 420; Martin Hedemann-Robinson, Enforcement of International Environmental Law (2019).

2 Dispute Regarding Navigational and Related Rights (Costa Rica v. Nicaragua), Judgment, I.C.J. Reports 2009, p. 213, [64] ('Navigational and Related Rights'). See also Eirik Bjorge, The Evolutionary Interpretation of Treaties (2014), 2.

3 Campbell McLachlan, "The Principle of Systemic Integration and Article 31(3)(c) of the Vienna Convention", 54 International and Comparative Law Quarterly (2005), 279, 29o; Panos Merkouris, Article 31(3)(c) VCLT and the Principle of Systemic Integration (2015), 300. See also ILC, "Fragmentation of International Law: Difficulties Arising from the Diversification and Expansion of International Law", UN Doc. A/CN.4/L.682 (13 April 2006).

4 Award in the Arbitration regarding the Iron Rhine ("Ijzeren Rijn") Railway (Belgium v. Netherlands) (2005) 27 RIAA 35 . 
into a treaty, whether or not that treaty itself targets environmental issues. It investigates patterns across three key variables: (1) the tribunal's readiness to adopt environmental claims; (2) the interpretative techniques the tribunal adopts to incorporate environmental norms; and (3) the tribunal's engagement with, and source-based substantiation of, environmental norms. In this regard, this article finds that, while these variables are influenced by a number of factors, including the type of claim litigated and the norm itself, the determinative factor is the treaty's temporality, or, in other words, the time of the treaty's conclusion relative to the emergence of international environmental law, and the treaty's relationship with this legal regime.

This article proceeds in three parts. First, it establishes the connection between intertemporality and interpretative techniques, commenting on the paucity of scholarship considering this relationship's impact on the judicial incorporation of environmental law. Second, it outlines this study's scope, and sets out a methodology for resolving the gap identified in the literature. Third, drawing on a survey of selected cases in which environmental norms have been invoked through interpretation, it discusses trends in jurisprudence, vis-à-vis the three variables noted above. This article does not intend to consider every relevant case in depth; rather, by identifying central cases, it aims to demonstrate the malleability of interpretative techniques, and the differing treatments of environmental law that result from intertemporal constraints. Such an investigation is particularly significant for environmental law, given its relevance to, and concomitant application in, disputes across all sectors of State activity.

\section{$2 \quad$ Outlining the Problem}

An evolutive approach to interpretation, and the techniques adopted to achieve it, allow tribunals to adapt otherwise fixed obligations to factual and legal developments that alter the situations in which the obligations were originally intended to apply. This raises the question of intertemporality more broadly; namely, the extent to which a tribunal, hearing a claim long after the relevant treaty's conclusion - and thus distanced from its context - can give adequate effect to the parties' intent as expressed in the treaty's terms. Historically, the principle of contemporaneity was deemed to apply, whereby treaties were interpreted in light of the law at the time of their conclusion. ${ }^{5}$ However, this

5 See, e.g., Gerald Fitzmaurice, "The Law and Procedure of the International Court of Justice 1951-4: Treaty Interpretation and Other Points", 33 British Yearbook of International Law 
approach was not adopted by the Vienna Convention on the Law of Treaties ('VCLT') ${ }^{6}$ due to the issue's complexity, ${ }^{7}$ nor by the ICJ in its advisory opinion on Namibia. ${ }^{8}$ Rather, the more satisfactory solution to the intertemporal problem incorporates the competing elements of stability - that obligations are definite and ascertainable - and change - that obligations should survive throughout a treaty's life, following developments in the corpus juris applicable to the State, or factual circumstances. ${ }^{9}$ Tribunals have largely implicitly approached intertemporality according to this balance, using party intention as the determinative factor in prioritising one element over another: ${ }^{10}$ they aim to interpret a treaty according to the law by which it was intended to be interpreted. This practice accounts for stark differences between tribunals' findings on the relevance of contemporary legal norms to older treaties. In his separate opinion in Gabčikovo-Nagymaros, for example, Judge Weeramantry commented that the relevant environmental standards for determining compliance were those extant at the time of application: "environmental rights are human rights ... [and treaties] cannot be applied in such a manner as to constitute a denial of human rights as understood at the time of their application".11 Conversely, the Tribunal in the OSPAR Arbitration found that it was not "authorized to apply 'evolving international law and practice' and cannot do so", and that Gabčikovo-Nagymaros had not suggested that tribunals had an inherent authority to apply law in statu nascendi. ${ }^{2}$

(1957), 203, 212; Humphrey Waldock, "Third report on the law of treaties", Yearbook of the International Law Commission, Vol. II (1964), 6, 9. These authors have been critiqued for misconstruing the cases they cite in support of this proposition: Julian Wyatt, Intertemporal Linguistics in International Law: Beyond Contemporaneous and Evolutionary Treaty Interpretation (2020), 26-33. Cf. Judge Weeramantry's reference to the "principle of contemporaneity" in Gabčkovo-Nagymaros as indicating an evolutive approach: Gabčikovo-Nagymaros Project (Hungary/Slovakia), Judgment, I.C.J. Reports 1997, p. 7, 113115 (Judge Weeramantry) ('Gabčíkovo-Nagymaros').

6 (opened for signature 23 May 1969, entered into force 27 January 1980) 1155 UNTS 331.

7 Merkouris, supra note 3, at 117.

8 Legal Consequences for States of the Continued Presence of South Africa in Namibia (South West Africa) notwithstanding Security Council Resolution 276 (1970), Advisory Opinion, I.C.J. Reports 1971, p. 16. The ICJ (at 31) reformulated the principle of contemporaneity, considering that required its interpretation according to "the intentions of the parties at the time of its conclusion", unless the concepts were "by definition" evolutionary. Merkouris, supra note 3, at 120-125.

10 Ibid., p. 159. See, e.g., the approaches taken in Island of Palmas case (Netherlands/USA) (1928) 2 RIAA 829; Aegean Sea Continental Shelf, Judgment, I.C.J Reports 1978, p. 3.

11 Gabčikovo-Nagymaros (Weeramantry), 114. 
Thus, this article posits the following hypothesis: a tribunal's willingness to engage with environmental norms is tied not to the treaty's age, but to its ability to ascertain an intention that the treaty be interpreted according to the law at the time of interpretation. Further, while this pertains to whether or not the treaty was intended to evolve at all, a tribunal will also refrain from the integration of certain subsequent developments where this implication would contradict party intention. For example, a treaty explicitly stating that environmental law is not relevant would preclude any interpretation based on environmental norms, regardless of its evolutive nature.

This hypothesis remains untested in the literature. Scholars who provide comprehensive appraisals of interpretation, or discuss particular processes, have necessarily focused on the interpretative tools themselves, at the expense of in-depth case studies. ${ }^{13}$ Similarly, discussions of intertemporal law, and its manifestation in international decisions, provide helpful contextual and analytical guidance, but do not focus on environmental law. ${ }^{14}$

A regime-driven analysis of interpretative processes has been applied to two areas: human rights, and the law of the sea. Discussions of evolutive interpretation in the context of human rights have been fairly comprehensive, ${ }^{15}$ and at points overlap with environmental law, on account of the environmental human rights provided for in human rights instruments. ${ }^{16}$ Treaty interpretation has also been considered vis-à-vis the law of the sea, most notably in the contributions to Del Vecchio and Virzo's 2019 co-edited volume:17 again, this

13 See, e.g., Julian Arato, "Subsequent Practice and Evolutive Interpretation: Techniques of Treaty Interpretation over Time and Their Diverse Consequences", 9 The Law and Practice of International Courts and Tribunals (2010), 443; Giovanni Distefano, "L'Interprétation Évolutive de la Norme Internationale", 115(2) Revue générale de droit international public (2011), 373 .

14 See, e.g., Rosalyn Higgins, "Time and the Law: International Perspectives on an Old Problem", 46 International and Comparative Law Quarterly (1997), 501; Malgosia Fitzmaurice, "Dynamic (Evolutive) Interpretation of Treaties", 21-22 Hague Yearbook of International Law (2008-2009), 101, 3.

15 See, e.g., Adamantia Rachovitsa, "The Principle of Systemic Integration in Human Rights Law", 66 International and Comparative Law Quarterly (2017), 557; Francisco Pascual-Vives, Consensus-Based Interpretation of Regional Human Rights Treaties (2019).

16 See, e.g., African Charter on Human and Peoples' Rights (opened for signature 27 June 1981, entered into force 21 October 1986) 520 UNTS 217, Art. 24; ASEAN, ASEAN Human Rights Declaration (18 November 2012), available at https://www.asean.org/wp-content/uploads/ images/resources/ASEAN\%2oPublication/2013\%2O(7.\%20Jul)\%20-\%2OASEAN\%2O Human\%2oRights\%2oDeclaration\%2o(AHRD)\%2oand\%2OIts\%2oTranslation.pdf, [28(f)].

17 Angela Del Vecchio and Roberto Virzo (eds.), Interpretations of the United Nations Convention on the Law of the Sea by International Courts and Tribunals (2019). 
area intersects with environmental law, with many environmental cases arising within the United Nations Convention on the Law of the Sea ('UNCLOs') ${ }^{18}$ framework. However, in all of these investigations, environmental law has not been the focal point: it therefore warrants a separate, dedicated investigation.

Interpretation with respect to environmental law is understudied. Boisson de Chazournes, for example, only very briefly discusses the "contamination" of environmental law in other treaties, ${ }^{19}$ while Mileva and Fortuna's chapter concentrates on the branch's relationship with human rights. ${ }^{20}$ Akhtar-Khavari explores international environmental law and its interaction with intertemporal law, ${ }^{21}$ primarily in relation to the Gabčíkovo-Nagymaros dispute. French provides the most detailed study to date; however, he focuses on interpretative techniques, and cites cases raising environmental issues only as examples. ${ }^{22}$ Similarly, Tanaka does not integrate his discussion of interpretative techniques with his analysis of the customary content of various environmental norms. ${ }^{23}$ Further, there is considerable literature engaging with the environmental practice of courts, ${ }^{24}$ and the development of environmental norms more generally; ${ }^{25}$ these, however, tend to lack discussion of interpretation. Conversely, articles dedicated to individual decisions do not offer a comparative approach, even

18 (opened for signature 10 December 1982, entered into force 16 November 1994) 1833 UNTS 397 .

19 Laurence Boisson de Chazournes, "Environmental Treaties in Time", 39(6) Environmental Policy and Law (2009), 293.

$20 \quad$ Nina Mileva and Marina Fortuna, "Environmental Protection as an Object of and Tool for Evolutionary Interpretation", in G. Abi-Saab et al. (eds.), Evolutionary Interpretation and International Law (2019), 123 .

21 Afshin Akhtar-Khavari, "The Passage of Time in International Environmental Disputes", 10(4) Murdoch University Electronic Journal of Law (2003), 43.

22 Duncan French, "Treaty Interpretation and the Incorporation of Extraneous Legal Rules", 55 International and Comparative Law Quarterly (2006), 281.

23 Yoshifumi Tanaka, "Reflections on Time Elements in the International Law of the Environment", 73 Zeitschrift für ausländisches öffentliches Recht und Völkerrecht (2013), 139.

24 See, e.g., Malgosia Fitzmaurice, "The International Court of Justice and International Environmental Law", in C.J. Tams and J. Sloan (eds.), The Development of International Law by the International Court of Justice (2013), 354; James Harrison, "Reflections on the Role of International Courts and Tribunals in the Settlement of Environmental Disputes and the Development of International Environmental Law", 25(3) Journal of Environmental Law (2013), 5 o1.

25 See, e.g., Philippe Sands, "International Courts and the Application of the Concept of 'Sustainable Development", 3 Max Planck Yearbook of United Nations Law (1999), 389; Jonathan B. Wiener, "Something Borrowed for Something Blue: Legal Transplants and the Evolution of Global Environmental Law", 27(4) Ecology Law Quarterly (2001), 1295. 
where they engage with interpretation. ${ }^{26}$ Thus, a case-driven study of evolutive interpretation in environmental law - to French, "arguably the topic-area where other sources of law have most often been utilised within the treaty interpretation process ${ }^{\prime 27}$ - remains a desideratum of the field; the present article intends to remedy that gap.

\section{$3 \quad$ Methodology and Scope}

This article is based on a comprehensive investigation of the jurisprudence of the International Court of Justice ('ICJ'), the International Tribunal for the Law of the Sea ('ITLOS'), ad hoc arbitral tribunals, arbitral tribunals constituted under UNCLOS, and the World Trade Organisation ('WTO')'s Dispute Settlement Body. Relevant terms were used to search the records of judgments by each tribunal, and these results were cross-referenced with scholarship outlining cases pertaining to environmental law. ${ }^{28}$ Of these cases, those in which tribunals used interpretation to incorporate environmental obligations not found in the treaty under discussion were identified. ${ }^{29}$ These key cases were then analysed with a view to articulating precisely what interpretative methods were adopted, and how the environmental norm was articulated and used, with patterns between cases identified.

This article aims to represent jurisprudential approaches across a range of arbitral and judicial fora; however, it proceeds on the assumption that courts and tribunals are largely consistent in their approach: differences based on

26 See, e.g., Alan Boyle, "The Gabčíkovo-Nagymaros Case: New Law in Old Bottles", 8 Yearbook of International Environmental Law (1997), 14; Cymie R. Payne, "Environmental Impact Assessment as a Duty under International Law: The International Court of Justice Judgment on Pulp Mills on the River Uruguay", 1 European Journal of Risk Regulation (2010), 317; John R. Cook, "In re Indus Waters Kishenganga Arbitration (Pakistan v. India)", 108(2) American Journal of International Law (2014), 308.

27 French, supra note 22, at 284.

28 The International Environmental Law Reports Series (1999-2007), and Darren Abraham and James Harrison's "Significant International Environmental Law Cases" series in the Journal of Environmental Law were relied on, in addition to cases raised in the literature more generally.

29 See, e.g., Legality of the Threat or Use of Nuclear Weapons, Advisory Opinion, I.C.J. Reports 1996, p. 226, [27]-[33] ('Nuclear Weapons'), in which environmental norms were applied to the customary understanding of the law of armed conflict. See also Certain Activities Carried Out by Nicaragua in the Border Area (Costa Rica v. Nicaragua) and Construction of a Road in Costa Rica along the San Juan River (Nicaragua v. Costa Rica), Judgment, I.C.J. Reports 2015, p. 665, in which Costa Rica alleged several breaches of customary environmental law norms. 
forum are not investigated. ${ }^{30}$ As the cases assessed make clear, each tribunal considers itself bound by the VCLT, on the basis that its provisions on interpretation (Articles $3^{1}$ to 33 ) are deemed a mirror of customary international law. ${ }^{31}$ Although the VCLT provides little guidance on evolutive approaches, ${ }^{32}$ tribunals adopting such approaches seek to align their reasons with the Convention's established principles. Furthermore, tribunals tend to consider the international legal order as a homogenous system: the goal of consistency including in interpretative approach ${ }^{33}$ - is implicit in their decisions. ${ }^{34}$

Similarly, although tribunals have become more willing to engage with environmental law over time, norms have only been invoked routinely over the past 20 years. ${ }^{35}$ The selected cases reflect that recency.

This survey is restricted in two further ways.

First, it focuses on interstate cases concerning treaty obligations. In each case, the matter involves only States, is heard in an international forum, and concerns the interpretation and application of an international instrument, with the environmental norm arising from that interpretation. This limitation avoids complications resulting from differences in domestic environmental obligations and domestic interpretative approaches to international obligations between States. Rather, the study intends to provide a more generalist analysis of interstate relations, and the enforcement of obligations in fora open to most States.

This criterion, significantly, excludes cases where express terms in the applicable treaty, or the interpretative approach applied to it, invoke those environmental obligations imposed by domestic or supranational systems. This primarily arises in expropriation claims in the context of investor-State

$30 \quad$ See Eirik Bjorge, "The Convergence of the Methods of Treaty Interpretation: Different Regimes, Different Methods of Interpretation?", in M. Andenas and E. Bjorge (eds.), A Farewell to Fragmentation: Reassertion and Convergence in International Law (2015), 498, 533. Cf. Joost Pauwelyn and Manfred Elsig, "The Politics of Treaty Interpretation:Variations and Explanations Across International Tribunals", in J.L. Dunoff and M.A. Pollack (eds.), Interdisciplinary Perspectives on International Law and International Relations (2012), 445.

31 See, e.g., Indus Waters Kishenganga Arbitration (Pakistan v. India) (2013) 31 RIAA 1 (Partial Award), [401]; Iron Rhine, [45]; Pulp Mills on the River Uruguay (Argentina v. Uruguay), Judgment, I.C.J. Reports 2010, p. 14, [65].

32 See Section 2 above.

33 Chester Brown, The Common Law of International Adjudication (2010), 12.

34 Pierre-Marie Dupuy, "Competition among International Tribunals and the Authority of the International Court of Justice", in U. Fastenrath et al. (eds.), From Bilateralism to Community Interest: Essays in Honour of Bruno Simma (2011), 862, 869 .

35 Jorge Viñuales, "The Contribution of the International Court of Justice to the Development of International Environmental Law", 32 Fordham International Law Journal (2008), 232. 
treaty regimes: in these, governments may seek to prevent the operation of a venture liable to cause environmental damage on the basis of domestic environmental legislation. ${ }^{36}$ Under the General Agreement on Tariffs and Trade ('GATT'), ${ }^{37}$ parties may invoke Article $\mathrm{XX}$ as a defence to alleged breaches: the provision permits otherwise non-compliant domestic measures made in respect of one of a list of exhaustive matters, including to "protect human, animal or plant life or health". Cases brought pursuant to these treaties have engaged with issues of intertemporality: a tribunal may interpret a provision requiring deference to domestic legislation as incorporating subsequent environmental legislation, even though that type of domestic legislation was not envisaged by the parties upon accession. ${ }^{38}$ However, as this invocation of environmental law relies on the operation of pre-existing domestic provisions, the application of which is merely facilitated by the tribunal's interpretation of an international treaty, such instances fall beyond the scope of this article. Similarly, while the European Court of Justice has actively engaged with environmental law, with environmental protection being an "essential objective" of European Community law, ${ }^{39}$ the supranational nature of this regime places it beyond this article's scope. ${ }^{40}$

Second, the article excludes from its scope all cases brought pursuant to human rights treaties, including those between States in international fora. These treaties have frequently been used by individuals seeking prevention of, or compensation for, environmentally harmful activities. The European Court of Human Rights ('ECtHR'), for example, has considerable jurisprudence extending the right to a private life under Article 8 of the European Convention on Human Rights ${ }^{41}$ to encompass a prohibition on hazardous activities near residential areas, ${ }^{42}$ and domestic European courts have interpreted the article

36 See, e.g., SD Myers v. Canada (Partial Award) (2001) 40 ILM 1408, [261]-[263]; Reinhard Hans Unglaubev. Republic of Costa Rica (Award) (ICSID, Case No. ARB/og/2O, 16 May 2012).

37 (opened for signature 3o October 1947, entered into force 1 January 1948) 55 UNTS 194.

38 See also Navigational and Related Rights, [89].

39 Natalie Klein, "Settlement of international environmental law disputes", in M. Fitzmaurice, D.M. Ong and P. Merkouris (eds.), Research Handbook on International Environmental Law (2010), 379, 393 .

40 On the development of environmental law see, e.g., Ludwig Krämer, "The Environment before the European Court", in C. Voigt (ed.), International Judicial Practice on the Environment (2019), 25 .

41 (opened for signature 4 November 1950, entered into force 3 September 1953) 213 UNTS 221.

42 See, e.g., López Ostra v. Spain (1995) 20 EHRR 277; Tătar v. Romania (ECtHR, Application No. 67021/o1, 6 July 2009). 
as binding States to their commitments regarding environmental protection. ${ }^{43}$ Further, the Inter-American Court of Human Rights' Advisory Opinion on the Environment and Human Rights held that the American Convention on Human Rights $^{44}$ implicitly includes a right to a healthy environment, given its instrumentality to the enjoyment of other rights under the Convention; the Court also extended the Convention's jurisdictional scope to cross-border effects, thus allowing human rights claims based on transboundary environmental harm. ${ }^{45}$ However, tribunals in this arena tend not to apply environmental norms, but rather merely recognise environmental harm as injurious to human rights. Furthermore, these bodies have developed a distinct doctrine of intertemporality not reflected in international law more generally; ${ }^{46}$ as such, their adoption of environmental norms indicates a willingness to integrate modern social values into human rights treaties, rather than environmental law per se. While these cases were thus excluded in the present survey, scholarship on the interaction between environmental and human rights law remains a fruitful source for comparative study. ${ }^{47}$

As above, the focus of this article is the interpretative approach taken by international courts and tribunals when incorporating contemporary environmental norms in treaties lacking these same norms, and the results thereof.

43 The Netherlands v. Urgenda Foundation (Hague Court of Appeal, Case No. 200.178.245/o1, 9 October 2018).

44 (opened for signature 22 November 1969, entered into force 18 July 1978) 1144 UNTS 123.

45 Medio ambiente y derechos humanos (Obligaciones estatales en relación con el medio ambiente en el marco de la protección y garantía de los derechos a la vida y a la integridad física - Interpretación y alcance de los artículos 4.1 y 5.1, en relación a los artículos 1.1. y 2 de la Convención Americana sobre Derechos Humanos) ['The Environment and Human Rights (State Obligations in Relation to the Environment in the Context of the Protection and Guarantee of the Rights to Life and to Personal Integrity - Interpretation and Scope of Articles 4(1) and 5(1) of the American Convention on Human Rights)'] (Advisory Opinion) (IACtHR, Case No. OC-23/17, 15 November 2017).

46 Liliana E. Popa, Patterns of treaty interpretation as anti-fragmentation tools: a comparative analysis with a special focus on the ECtHR, WTO and ICJ (2017), 9. See RosInvest Company UK Limited v. Russian Federation (Award on Jurisdiction) (sCC, Case No. Vo79/2005, 1 October 2007), [39].

47 See, e.g., Donald K. Anton and Dinah Shelton, Environmental Protection and Human Rights (2011); John H. Knox and Ramin Perjan (eds.), The Human Right to a Healthy Environment (2018). 
This investigation considers trends across three key variables shared between the selected cases:

1. whether the tribunal was willing to accept arguments on the relevance of environmental norms to the dispute;

2. if so, the interpretative techniques relied upon to incorporate the norm within the dispute's ambit; and

3. how the tribunal then engaged with the particular norm and concomitant obligation, including its effect, breadth and basis.

As the discussion below explicates, each variable is primarily dependent on the underlying treaty's interaction with intertemporality. In other words, how each variable manifests in a case is predicated on whether the treaty evinces an intention that it be interpreted according to modern developments, and whether it indicates any objection to the incorporation of environmental law itself. Given the centrality of intertemporality in this discussion, the treaties interpreted in the selected cases have been categorised according to the drafters' knowledge of, and intention with respect to, environmental law and legal change more broadly. This categorisation allows for the easier identification of jurisprudential trends.

First, some drafters, while aware of environmental norms, declined to include them in treaties in which they might otherwise be relevant (Category 1). Second, other drafters failed to include norms due to the treaties' conclusion preceding the international environmental legal regime's emergence, but evinced a broader intention that the treaties' obligations evolve (Category 2). Third, others yet, though open to environmental law, drafted treaties on the cusp of the regime's emergence, and therefore engaged with principles only tentatively and implicitly (Category 3). Only the final category of drafter was able to, and explicitly chose to, include a number of (albeit, underdeveloped) environmentally-focused provisions (Category 4).

UNCLOS, for example, falls in Category 4: it is often described as an environmental treaty, ${ }^{48}$ and its Part XII comprises an extensive set of provisions pertaining to the protection of the marine environment. However, having been drafted in the late 1970s and early 1980s, following the first major multilateral treatment of environmental law in the StockholmDeclaration, ${ }^{49}$ the Convention

48 See, e.g., Jonathan Charney, "The Marine Environment and the 1982 Convention on the Law of the Sea", 28 International Lawyer (1994), 879, 882; James Harrison, Saving the Oceans through Law: The International Legal Framework for the Protection of the Marine Environment (2017), 304.

49 Report of the UN Conference on the Human Environment (1972), UN Doc. A/CONF.48/14 ('Stockholm Declaration'). 
reflects the nascent principles extant at that time. ${ }^{50}$ Indeed, Mossop has commented on UNCLOS' failure to fulfil its environmental label, ${ }^{51}$ and posits that only tribunals' willingness to incorporate customary international law, on the basis of the treaty's environmental purpose, ensures environmental law's applicability in the sector.

The cases selected as the foci for analysis, and their categorisation, are as follows:

I. Treaties excluding environmental norms:

- Indus Waters Kishenganga Arbitration (Pakistan v. India) (2013) 31 RIAA 1, Partial Award of 18 February 2013 ('Indus Waters (Partial Award)'); Final Award of 20 December 2013 ('Indus Waters (Final Award)')

II. Historic treaties:

- Award in the Arbitration regarding the Iron Rhine ("Ijzeren Rijn") Railway (Belgium v. Netherlands) (2005) 27 RIAA 35 ('Iron Rhine')

- United States - Import Prohibition of Certain Shrimp and Shrimp Products WT/DS58/AB/R (Appellate Body Report, 12 October 1998) ('Shrimp-Turtle')

III. Treaties engaging with early environmental law:

- Pulp Mills on the River Uruguay (Argentina v. Uruguay), Provisional Measures, Order of 13 July 2006, I.C.J. Reports 2006, p. 113 ('Pulp Mills (Provisional Measures)'); Judgment, I.C.J. Reports 2010, p. 14 ('Pulp Mills')

- Gabčikovo-Nagymaros Project (Hungary/Slovakia), Judgment, I.C.J. Reports 1997, p. 7 ('Gabčíkovo-Nagymaros')

IV. 'Environmental' treaties:

- The South China Sea Arbitration (The Republic of Philippines v. The People's Republic of China) (Merits) (PCA Case No. 2013-19, 2 July 2016) ('South China Sea Arbitration')

- Responsibilities and obligations of States with respect to activities in the Area, Advisory Opinion, 1 February 2011, ITLOS Reports 2011, p. 10 ('Advisory Opinion on the Area')

$5^{\circ}$ Ellis notes that conservation-focused provisions put forward by coastal States at the UNCLOS negotiations did not appear in the final draft, indicating some reticence towards the precise encapsulation of emerging principles: Jaye Ellis, "The Straddling Stocks Agreement and the Precautionary Principle as Interpretive Device and Rule of Law", 32(4) Ocean Development and International Law (2001), 289, 291.

51 Joanna Mossop, "Can we Make the Oceans Greener? The Successes and Failures of UNCLOS as an Environmental Treaty", 49 Victoria University of Wellington Law Review (2018), 573, 575 . 
The discussion below is structured by variable. Within every section, each category of treaty is represented, unless insufficient evidence arises for a category. The different effects of each category on the relevant variable are discussed through a detailed explanation of the applicable cases, with additional influential factors then set out.

\subsection{The Tribunal's Willingness to Invoke Norms}

Under what circumstances will a tribunal allow a claim based on modern environmental norms to affect a treaty-based dispute? While a number of interpretative devices potentially facilitate the inclusion of contemporary norms in the interpretative process, the 'rules' of interpretation are such that this invocation does not necessarily need to occur. Interpretation provides a set of guiding principles to be followed; however, as there is no "mechanical method of ascertaining meaning", tribunals can justify a number of different interpretations of the same text. ${ }^{52}$

Tribunals considering treaties without, or with only limited, environmental provisions (Categories 1 and 3) are reticent to accept jurisdiction over claims based on environmental law, even when the treaty on its face allows for these. In particular, the tribunals in both Indus Waters and Pulp Mills took an unjustifiably narrow approach to treaty terms, eschewing consideration of context and purpose so as to prevent extraneous environmental claims, while still accepting some environmental norms for specific uses. ${ }^{53}$ While this may also be reflected within Category 2 treaties, there was insufficient evidence to substantiate this claim.

Indus Waters (Category 1) concerned the construction of a project on Pakistan and India's shared watercourses, pursuant to the 196o Indus Waters Treaty. ${ }^{54}$ Pakistan disputed India's entitlement to divert the watercourses and diminish the reservoir level of a run-of-river plant in a non-emergency scenario. The Tribunal in its Partial Award limited the environmental claims pleaded by adopting a textual approach to the treaty: it found that Article IV(6) requiring parties to avoid "any obstruction to the flow in [the rivers' natural channels] likely to cause material damage to the other Party" - solely concerned the physical condition of the channels. ${ }^{55}$ This was contrary to Pakistan's contention that "material damage" encompassed loss of natural habitat and

$52 \quad$ Richard Gardiner, Treaty Interpretation (2nd edition, 2017), 483-484. See also ILA Study Group on the Content and Evolution of the Rules of Interpretation, "Working Session Report of the ILA 7oth Biennial Conference" (2021) [forthcoming].

53 See Indus Waters (Partial Award), [373]; Pulp Mills (Merits), [56]-[62].

54 (signed 19 September 196o, entered into force 1 April 196o) 419 UNTS 210.

55 Indus Waters (Partial Award), [373]. 
ecosystem functions, the protection of which was required by international environmental norms. ${ }^{56}$ The Tribunal's conclusion was made on the basis of the provision's ordinary meaning, informed by the travaux préparatoires. However, the VCLT, on which the Tribunal expressly relied as an authoritative source for interpretative methodology, ${ }^{57}$ promotes reliance on elements beyond the ordinary meaning of the words ${ }^{58}$ - terms are to be considered "in their context and in the light of [the treaty's] object and purpose" 59 - and indeed, the Tribunal followed this formulation elsewhere. ${ }^{60}$ The approach taken is also surprising: the term 'material damage' read plainly has a broad semantic range, and would appear to cover the circumstances alleged by Pakistan. The provision's context provides further support: Article IV concerns the river system generally, and includes protections for soil against erosion and dredging. ${ }^{61}$ The Tribunal's substantiation of its textual approach through the travaux préparatoires was also inappropriate: given their unreliability, ${ }^{62}$ such extraneous documents may only confirm an ambiguous, obscure, or absurd meaning subsequent to application of the general interpretative rule. ${ }^{63}$ Altogether, the Tribunal's patchwork use of interpretation, in contrast to its full application later in its Partial Award, betrays its interest in excluding possible environmental claims.

Similarly, in Pulp Mills (Category 3), the ICJ found that it lacked jurisdiction to determine breaches of obligations under other international agreements and general law through an uncharacteristically narrow analysis of treaty provisions that Argentina argued were referral clauses. ${ }^{64}$ Argentina claimed several alleged procedural and substantive breaches by Uruguay of the 1975 Statute of the River Uruguay, ${ }^{65}$ arising from Uruguay's authorisation of the смв Mill's construction, and the Botnia Mill's construction and commission, on the river constituting the boundary between the two States. When determining whether the treaty adopted external norms and instruments, the Court used the treaty's authentic Spanish text, which relevantly provided in English translation that the parties agreed "in order to establish the joint machinery ... [and]

$56 \quad$ Ibid., [257].

57 Cf. ibid., [401]-[414], where the Tribunal considered the vCLT Article 31 elements in full, having cited this provision as outlining the "fundamental rules" of treaty interpretation.

58 Gardiner, supra note 52, at 162.

$59 \quad$ VCLT, Art. 31.

6o See, e.g., Indus Waters (Partial Award), [365].

$61 \quad$ Indus Waters Treaty, $\operatorname{Art} \operatorname{Iv}(3)$.

62 Anthony Aust, Modern Treaty Law and Practice (3rd edition, 2013), 217.

63 VCLT, Art. 32. Even under the expansive view Gardiner espouses, the provision cannot displace Article 31: supra note 52, at 353 .

64 See Pulp Mills (Merits), [56]-[62].

65 (Signed 26 February 1975, entered into force 18 September 1976) 1295 UNTS 340. 
in strict observance of the rights and obligations arising from treaties ... in force for each of the parties". The Court found that the use of $y$ ('and') before the phrase concerning external treaties limited those treaties' applicability to the implementation of the treaty itself, as they were linked to the parties' agreement. Similarly, it found that the reference to treaties in force for cualquiera ('any') party - not 'each' - indicated that the provision only acknowledged the parties' existing commitments. The Court took a similarly restrictive approach to Article 41 of the treaty, finding that the undertaking to protect and preserve the aquatic environment by adopting measures in accordance with applicable international agreements did not incorporate those agreements, but rather required States to exercise regulatory powers in conformity with them.

In making these findings without further consideration of context, object or purpose, the Court departed from its usual holistic approach to interpretation. ${ }^{66}$ Indeed, an expansive approach in light of the treaty's object and purpose, and reflected in subsequent State practice, was available. In oral proceedings, Professor Boyle, representing Argentina, noted that Uruguay's authorisation for the Botnia Mill expressly required it to comply with the Stockholm Convention on Persistent Organic Pollutants, ${ }^{67}$ indicating that Uruguay considered itself bound by external agreements in the course of its conduct. ${ }^{68}$ Most pertinently, it appears from oral argument that Uruguay agreed with Argentina's interpretation of Article 41 as a referral clause. ${ }^{69}$

Those cases may be contrasted with ITLos' Advisory Opinion on the Area (Category 4). The Seabed Disputes Chamber had been requested to determine States' obligations with respect to the Area, and ultimately found that developing States were held to the same standard as all States. ${ }^{70}$ Although not called upon to discuss Environmental Impact Assessments ('EIAs'), the Chamber did so regardless, and found that the more specific articulation of the obligation to undertake an EIA in the Nodules and Sulphides Regulations was applicable to all States. ${ }^{71}$ It may be suggested that this approach is attributable to tribunals'

\footnotetext{
66 See Liliana E. Popa, "The Holistic Interpretation of Treaties at the International Court of Justice", 87 Nordic Journal of International Law (2018), 249.

67 (opened for signature 22 May 2001, entered into force 17 May 2004) 2256 UNTS 119.

68 Pulp Mills, Oral Transcript CR 2006/47 (translation), [37].

69 Pulp Mills, Oral Transcript CR 2006/48 (translation), [14].

70 Advisory Opinion on the Area, [158].

71 Advisory Opinion on the Area, [147]-[150].
} 
tendency to overstep their conferred jurisdiction in advisory opinions, ${ }^{72}$ a consequence of advisory opinions' non-binding nature, ${ }^{73}$ whereby extending jurisdiction does not increase States' liability. ${ }^{74}$ In Nuclear Weapons, for example, the Court adopted a broad reading of Article vi of the Treaty on the Non-Proliferation of Nuclear Weapons, unrelated to the questions asked. ${ }^{75}$ However, the South China Sea Arbitration (Category 4) - a contentious dispute involving consideration of UNCLOS - demonstrates a similar tendency. In that case, the Philippines sought a declaration that China's harvesting and construction activities breached UNCLOS' obligations relating to the protection and preservation of the marine environment: ${ }^{76}$ the Tribunal embraced each of the Philippines' contentions without revision, and invoked a number of environmental norms both within and external to the treaty, as discussed below. This indicates, at the very least, that UNCLOS' inherently environmental character means that tribunals interpreting it are more open to the invocation of contemporary environmental norms.

\subsection{The Tribunal's Choice of Interpretative Techniques}

A tribunal invoking environmental norms may do so on the basis of a myriad of interpretative techniques that allow for this process. A number allow direct incorporation, such as VCLT Article 31(3)(c), which requires an interpretation to take into account any relevant law applicable between the parties, and UNCLOS Article 293, which requires that tribunals apply compatible international legal rules in interpreting the Convention. Other techniques depend on the treaty, such as the concepts of 'generic' evolving terms, and the treaty's object and purpose. More generally, some tribunals merely note that certain treaties betray an evolutive intention, and adopt environmental norms on that basis.

72 Tullio Treves, "Advisory Opinions of the International Court of Justice", 4 Max Planck Yearbook of International Law (200o), 215, 216; Anthony Aust, "Advisory Opinions", 1(1) Journal of International Dispute Settlement (2010), 123, 146-151.

73 Interpretation of Peace Treaties, Advisory Opinion, I.C.J. Reports 1950, p. 65, 71.

74 Cf. Benvenuti, who concludes that both "decisions" and "Advisory Opinions" determine the rights and obligations of international legal subjects; there is, therefore, no practical distinction: Paolo Benvenuti, L'Accertamento Del Diritto Mediante I Pareri Consultivi Della Corte Internazionale Di Giustizia (1985).

75 Nuclear Weapons, [98]-[99]; Nuclear Weapons (Separate Opinion of Judge Guillaume), [13]. See also Daniel Joyner, "The legal meaning and implications of Article vi of the Non-Proliferation Treaty", in G. Nystuen, A.G. Bersagel and S. Casey-Maslen (eds.), Nuclear Weapons under International Law (2014), 397, 405.

$7^{6}$ South China Sea Arbitration, [112]. 
The following discussion investigates patterns in the usage of these techniques: it analyses circumstances where techniques may not be referred to at all, whether certain types of treaties preclude certain techniques, and finally, given these constraints, which techniques are preferred by tribunals in interpreting particular categories of treaty.

\subsubsection{Where No Interpretative Techniques are Adopted}

Tribunals habitually reference environmental norms without recourse to interpretative techniques justifying their invocation. In Pulp Mills (Provisional Measures), in which Argentina sought the suspension of the mills project, the ICJ raised a number of environmental norms - quoting its prior jurisprudence on the prohibition of transboundary harm, ${ }^{77}$ and commenting that the present case highlighted the importance of sustainable development ${ }^{78}$ - without relying on interpretative techniques. Ultimately, the Court found that any violation of environmental norms could be remedied at the merits stage, ${ }^{79}$ and that there was insufficient evidence to suggest irreparable damage, as required for the grant of provisional measures. ${ }^{80}$ The lack of engagement with environmental legal principles likely resulted from their irrelevance to the Court's conclusion: that the Court referred to them at all merely reflected the case's formulation by counsel. ${ }^{81}$

This same approach is also evident in the merits stage of the proceedings. The Court determined that the parties' utilisation of the River Uruguay through joint machinery should allow for sustainable development; however, quoting its prior decision in Gabčkovo-Nagymaros, the Court found that "[i]t is for the Parties themselves to find an agreed solution that takes account of the objectives of the Treaty". ${ }^{22}$ By reducing the concept to one of cooperation, the Court merely repeated the explicit obligation to establish joint machinery as to provide an "institutional framework for close and ongoing cooperation":83 the invocation of sustainable development thus had no impact on the interpretation of the treaty, and so no interpretative technique was required. The Court's later description of Article 27 of the treaty as embodying the

\footnotetext{
$77 \quad$ Pulp Mills (Provisional Measures), [72].

78 Ibid., [8o].

79 Ibid., [70]-[71].

8 o Ibid., [74].

81 Tim Stephens, "Sustainability Discourses in International Courts: What Place for Global Justice?", in Duncan French (ed.), Global Justice and Sustainable Development (2010), 37,55 .

82 Pulp Mills (Merits), [76].

83 Ibid., [84].
} 
"balance between economic development and environmental protection" 84 similarly had no effect on its decision. Although this conclusion is somewhat progressive - neither that Article nor the notification regime to which it refers specifically require consideration of the environment ${ }^{85}$ - several other provisions indicate this balance. ${ }^{86}$ Furthermore, the Court referenced the principle of prevention in determining when the notification scheme under Articles 7-12 was triggered, noting that it derived from the doctrine of due diligence, and formed part of general international law. ${ }^{87}$ However, the Court then found that the explicit obligation under those articles - to inform the river's administering body - allowed "the initiation of co-operation between the Parties which is necessary in order to fulfil the obligation of prevention".88 As such, satisfaction of the treaty obligation fulfilled the general international law obligation of prevention ipso facto: the external principle had no work to do, and so no interpretative basis was required for its consideration.

Similarly, in Gabčíkovo-Nagymaros, the Court discussed environmental norms in the context of legitimate grounds on which to terminate a treaty, and reaffirmed that the principle of prevention formed part of the corpus of general international law. ${ }^{89}$ However, as the Court found that environmental changes could not justify termination - meaning that Hungary could not justify its termination of the 1977 treaty governing its joint dams project with Slovakia ${ }^{90}$ on the basis of modern environmental norms - no further investigation of the norms' content was necessary. As such, it appears that tribunals refrain from referencing techniques primarily where they do not intend for a principle to impact their reasoning.

\subsubsection{Where Treaty Categories Preclude Certain Techniques}

Consideration of the treaty drafters' intention is fundamental to an assessment of intertemporal law. Where their intention to incorporate a given norm cannot exist - either because the relevant treaty was concluded prior

\footnotetext{
84 Ibid., [177].

85 Statute of the River Uruguay (signed 26 February 1975, entered into force 18 September 1976) 1295 UNTS 340, Art. 27 provides: "[t]he right of each party to use the waters of the river, within its jurisdiction, for domestic, sanitary, industrial and agricultural purposes shall be exercised [in accordance with the notification regime]".

86 Ibid., Chs. vir; IX.

87 See Pulp Mills (Merits), [101]-[105].

88 Ibid., [102].

89 Gabčíkovo-Nagymaros, [53].

90 Agreement concerning mutual assistance in the construction of the Gabčikovo-Nagymaros system of locks (signed 16 September 1977, entered into force 30 June 1978) 1724 UNTS 120.
} 
to the emergence of the surrounding regime, or because it excludes by omission the relevant category of norms - tribunals avoid the direct adoption of that norm (i.e., in Categories 1 and 2). This precludes the use of broadly applicable techniques, primarily the principle of systemic integration (as at VCLT Article $31(3)(c))$. Rather, tribunals in these decisions demonstrate a preference for establishing that the drafters intended that the treaty evolve so as to incorporate the contemporary norm, with Article 31(3)(c) being of secondary importance in their reasoning.

The Tribunal in Indus Waters (Partial Award) (Category 1) determined that India's right to divert the watercourses and diminish the reservoir level of a run-of-river plant in a non-emergency scenario was not absolute: Pakistan, under an express treaty provision, was owed a minimum flow, a reading confirmed upon interpretation in light of contemporary customary environmental law. ${ }^{91}$ In so interpreting, the Tribunal articulated the treaty's express terms on interpretation - which the Tribunal in fact relied on - as a mirror of the content of VCLT Article 31(3)(c). The former, however, provides a far more limited basis for invoking external norms, ultimately reflected in the Tribunal's findings. ${ }^{92}$ Similarly, the Tribunal drew on broader notions of systemic integration, as expressed by the ICJ in Gabčkovo-Nagymaros, merely to justify its ability to take into account contemporary norms, noting that this was required "even when (unlike the present case) interpreting treaties concluded before the development of that body of law" (emphasis added). ${ }^{93}$ This reflects the treaty's relationship with intertemporal law, and the consequent impact on interpretative techniques: as the relevant treaty was concluded after the emergence of environmental law, ${ }^{94}$ the drafters could have integrated this regime within the treaty, but, unlike many instruments governing international waters concluded at that time, chose not to. ${ }^{95}$ The explicit inclusion of a mechanism for systemic integration may have also tended against the Tribunal relying on

$91 \quad$ Indus Waters (Partial Award), [447].

92 Ibid., fn. 654. Indus Waters Treaty (signed 19 September 1960, entered into force 1 April 1960) 419 UNTS 210, Annexure G, [29] allowed consideration of custom "whenever necessary for [the treaty's] interpretation or application, but only to the extent necessary for that purpose", subsequent to the application of any relevant conventions to which both States were party.

93 Indus Waters (Partial Award), [452].

94 The Tribunal implicitly acknowledged this at [452].

95 See, e.g., Treaty Concerning the Regulation of Water Economy Questions in the Frontier Region (signed 9 April 1956, entered into force 31 July 1956) 438 UnTs 123; Agreement on the Protection of Lake Constance against Pollution (signed 27 October 1960, entered into force 10 November 1961) 620 UNTS 191. 
other interpretative techniques; however, the hesitant approach it took to its discussion of evolutive techniques generally indicates a broader opposition to affording environmental norms too large a role. Indeed, while the Tribunal could have relied on interpretative approaches associated with following party intention, such as the treaty's object and purpose, or generic terms, to incorporate new norms, ${ }^{96}$ the Tribunal avoided their consideration, likely due to the fact that the drafters explicitly did not intend the result.

Tribunals determining cases dealing with Category 2 treaties, on the other hand, are more willing to rely on VCLT Article 31(3)(c) itself. However, they deem the treaty evolutive as an initial step. The Tribunal in Iron Rhine, for example, in determining how the Treaty of Separation of $1839^{97}$ construed the modernisation of the railway built pursuant to it, as well as the apportionment of this project's costs, adopted a two-step interpretative process. The Tribunal only relied on Article 31(3)(c) after it had first found that the treaty was intended to evolve, on account of the treaty's object and purpose; ${ }^{98}$ this was despite the arbitral agreement explicitly allowing the direct incorporation of present norms. ${ }^{99}$ The Tribunal, in noting that the treaty's terms could evolve, abstracted the treaty from its historic circumstances prior to invoking Article $31(3)(c)$, and so allowed for incorporation of the current legal order (including environmental law), rather than the legal order at the time of the treaty's conclusion two centuries earlier. Such reticence likely arises from the notion that systemic integration conforms to drafter intention: ${ }^{100}$ for it to be used to integrate contemporary law, an evolutive intention must be established.

The Appellate Body in Shrimp-Turtle (Category 2) took a similar two-stage approach. This decision concerned whether the Us' discriminatory prohibition on shrimp imports based on turtle protection mechanisms fell within Article XX of the GATT, which permitted otherwise discriminatory measures

$9^{6}$ These techniques still could be used even where the treaty being interpreted deliberately excludes environmental law, as they merely require an intention that the treaty evolve generally: Sondre Torp Helmersen, "Evolutive Treaty Interpretation: Legality, Semantics and Distinctions", 6(1) The European Journal of Legal Studies (2013), 127, 135.

97 Treaty between Belgium and the Netherlands relative to the Separation of their Respective Territories (signed 19 April 1839) 88 CTS 427.

98 Iron Rhine, [82]. Note, however, the parallel purpose of this determination as a means of allowing the present dispute to be resolved by the treaty: the treaty's evolutive nature thus sustained changes in both factual and legal matrices.

99 French, supra note 22, at fn. 44.

100 Bjorge, The Evolutionary Interpretation of Treaties, supra note 2, at 2; Gardiner, supra note 5 , at $293-295$. 
for the conservation of "exhaustible natural resources". ${ }^{101}$ The Body set out the environmental object and purpose of the 1994 update to the GATT prior to deeming Article xx a generic term. ${ }^{102}$ Notably, however, the latter determination is sufficient to sustain evolution of itself, and, significantly, the 1994 treaty's object and purpose ought to be irrelevant to the interpretation of Article Xx, which remained unchanged from 1949. By contrast (and as will be discussed in Section 4.2.3 below), the tribunals in cases under Categories 3 and 4 do not consider the treaty's evolutive nature separately: both generic terms and systemic integration directly permit environmental considerations. ${ }^{103}$ This distinction reflects the greater significance of justifying the integration of environmental norms in those situations where party intention could not have foreseen the regime's development.

\subsubsection{Where Tribunals Prefer Certain Techniques for Invoking Norms} It appears that - unless the treaty is explicitly environmental in nature tribunals prefer to base evolutive treaty interpretation on generic terms, likely due to this technique's direct relationship to party intention and capacity to be ascertained from the text alone. If the parties intended a term to evolve, finding such evolution is justifiable; conversely, the use of VCLT Article31(3)(c) may appear to overstep intention in some cases, as it allows for the importing of external legal norms, regardless of whether the drafters intended this to occur. ${ }^{104}$ Further, the ICJ has found that generic terms must be presumed to evolve, as a consequence of intention. ${ }^{105}$ As French has argued, this allows tribunals to integrate developments under the guise of intention, regardless of the parties' actual intention, so long as the terms are sufficiently open. ${ }^{106}$ In situations where this is palatable - namely, where the treaty has not excluded environmental norms - it provides an accessible means to integrate modern law without further justification.

In Gabčkovo-Nagymaros, the ICJ found that several provisions relating to the creation of a joint contractual plan to protect the environment were

\footnotetext{
101 Shrimp-Turtle, [18].

102 Ibid., [22]-[23].

103 See, e.g., Gabč́kovo-Nagymaros, [112].

104 See, e.g., Oil Platforms (Islamic Republic of Iran v. United States of America), Judgment, I.C.J. Reports 2003, p. 161, 237 (Higgins); 278-280 (Buergenthal).

105 Aegean Sea, [77]; Navigational and Related Rights, [66].

106 French, supra note 22, at 297.
} 
evolutive in nature:107 as such, while modern environmental norms did not justify Hungary's termination of the 1977 treaty, any newly developed norms could be incorporated, by agreement, into the parties' relations. ${ }^{108}$ Similarly, in Pulp Mills, the obligation "to protect and preserve" the aquatic environment under Article 41 of the treaty was considered generic. ${ }^{109}$ In neither of these cases did the Court defend this analysis deeming the terms generic. Further, the Appellate Body in Shrimp-Turtle labelled the concept of "exhaustible natural resources" generic: while the Body supported the finding by reference to the underlying treaty's object and purpose, it too did not justify the 'generic' label.

Indeed, these approaches may be contrasted with the cases explored above. In Iron Rhine (Category 2), the Tribunal's use of Article 31(3)(c), instead of identifying a generic term, was out of necessity. The Tribunal initially discussed the evolutive effect of generic terms, but discounted this approach's applicability in the circumstances, as the dispute required consideration of external technical developments. ${ }^{110}$ On the other hand, the Tribunal's reliance in Indus Waters (Category 1) on systemic integration was likely due to the difficulty in legitimately finding an intention for terms to evolve to incorporate environmental law where this regime was clearly excluded. Rather, it was the treaty's express mandate there that provided a textual basis for the Tribunal to objectively ascertain an intention to draw in external norms.

Identifying generic terms is less pertinent where the underlying treaty is itself 'environmental'. In the cases brought under UNCLOS (Category 4), each tribunal's approach responds to that treaty's intentionally explicit environmental purpose, which implicitly justifies the invocation of environmental norms. Both the South China Sea Arbitration and the Advisory Opinion on the Area demonstrate the effects of this expansive basis: having discussed the significance of environmental protection to the UNCLOS regime, neither tribunal fully engaged with other interpretative techniques; rather, systemic integration both as a general principle, ${ }^{111}$ and through the explicit mechanisms of VCLT

\footnotetext{
107 Gabčíkovo-Nagymaros, [140].

108 Ibid., [112].

109 Pulp Mills (Merits), [193]-[197].

110 Iron Rhine, [8o].

111 See, e.g., the Tribunal's statement in South China Sea Arbitration at [941] that the corpus of international environmental law "informs the content of the general obligation".
} 
Article $31(3)(c),{ }^{112}$ UnCLOS Article 293, ${ }^{113}$ and UnCLOS Article $237^{114}$ - could be relied upon without further consideration of intention. ${ }^{115}$

Evolutive interpretation thus ultimately depends on ascertaining party intention, ${ }^{116}$ with tribunals chiefly considering objective intention - determined through the treaty text - rather than the drafters' state-of-mind, ${ }^{117}$ likely because the latter is less accessible and verifiable. The technique tribunals adopt tends to pursue drafter intention, to the full extent the treaty allows. It is likely for this reason that VCLT Article 31(3)(c) - a provision in a separate treaty, with little connection to party intention - is the least used: it appears in a supporting role, where all other techniques are unavailable, or where the underlying treaty inherently accepts the inclusion of environmental norms.

\subsection{Engagement with and Basis of Environmental Norms}

The above discussion on tribunals' habit of referencing norms without further engagement highlights a third key variable between cases: the character of the norm itself. This in turn raises three distinct issues: whether the norm invoked in fact affects the interpretation of a treaty provision, or indeed the outcome of the dispute; what content this norm is given; and what sources are used to justify its existence. Each is discussed in turn below.

112 Ibid., [274].

113 Ibid., [236]; Advisory Opinion on the Area, [51].

114 While that article provides that States should carry out other agreements on environmental protection in a manner consistent with the general principles and objectives of unClos, in the South China Sea Arbitration, the Tribunal's comment that it envisages "reference to specific obligations set out in other international agreements" indicates it construed the article as facilitating systemic integration: South China Sea Arbitration, [942]. See further Chie Kojima, "South China Sea Arbitration and the Protection of the Marine Environment: Evolution of UnCLOS Part XII Through Interpretation and the Duty to Cooperate", 21 Asian Yearbook of International Law (2015), 166, 172.

115 South China Sea Arbitration, [941]-[956]; Advisory Opinion on the Area, [110]-[117] (due diligence); [121]-[135] (precautionary approach).

116 Cf. Mileva and Fortuna, noting that scholars divide the bases into intention, object and purpose, and language used: supra note 20 , at 123 . It is this article's position that these bases all are used as a means of determining intention: see, e.g., Pierre-Marie Dupuy, "Evolutionary Interpretation of Treaties: Between Memory and Prophecy", in E. Cannizzaro (ed.), The Law of Treaties Beyond the Vienna Convention (2011), 123, 127.

117 "Subjective" intention may be ascertained through, for example, the treaty's unstated objectives, or preparatory documents: see generally, Gerald Fitzmaurice, "The Law and Procedure of the International Court of Justice: Treaty Interpretation and Certain Other Treaty Points", 28 British Yearbook of International Law (1951), 1. 
4.3.1 The Effect of Environmental Norms on the Case's Outcome

How a tribunal engages with the content of legal norms absent from, but relevant to, the treaty being interpreted, correlates to the underlying treaty's relationship with intertemporal law. Necessarily, the more a treaty allows for the integration of environmental law, the more the tribunal is willing to engage in this process. As such, where the underlying treaty excludes environmental law (Indus Waters), the effect of this body of law on the dispute is negligible; where the treaty either lacks the capacity to incorporate environmental law (Iron Rhine; Shrimp-Turtle) or does so to a minimal extent (Pulp Mills; Gabčikovo-Nagymaros), there is some engagement and application; and where the treaty's purpose concerns environmental protection, expansive integration and the application of a range of environmental norms is common (South China Sea Arbitration; Advisory Opinion on the Area).

By way of example, in Indus Waters (Category 1), the Tribunal's primary use of environmental law in the Partial Award was to substantiate its finding that a minimum flow for Pakistan was required: the Tribunal made this decision on the basis that the treaty terms indicated an intention to balance Pakistan's unrestricted use of the rivers against the express curtailments in the treaty; ${ }^{118}$ however, it noted that this conclusion "also stems from the Treaty's interpretation in light of customary international [environmental] law".119 Indeed, the Tribunal ultimately clarified that the parties had agreed that a minimum diversion was required, and differed only as to the level of the minimum, which it reserved for the Final Award. ${ }^{120}$ However, in the Final Award, the Tribunal severely constrained its references to environmental law: while the need to mitigate significant harm to the environment was to be taken into account, any findings beyond that were deemed prohibited by the treaty; it was neither appropriate nor necessary "to adopt a precautionary approach and assume the role of policymaker". ${ }^{21}$ Ultimately, the Tribunal settled on 9 cumecs as the minimum flow to Pakistan, a value lower than its determination of the minimum when exclusively considering environmental conditions - 12 cumecs - and far below Pakistan's claim of 20-40, but nonetheless higher than India's posited flow of $3 \cdot 94 .^{122}$

\footnotetext{
118 Indus Waters (Partial Award), [433].

119 Ibid., [447]. See also [448]-[451] for the Tribunal's discussion of the relevant norms, including the prohibition of transboundary harm; sustainable development; due diligence; and prevention.

120 Ibid., [455].

121 Indus Waters (Final Award), [112].

122 Ibid., [104].
} 
In Iron Rhine (Category 2), each party contended that the relevant treaty, controlling the construction of a road (extended to encompass the treaty's railway), imposed monetary liability according to a binary categorisation of the alterations: where the project constituted a new road or canal, Belgium was liable, while the Netherlands bore the full burden for maintenance. ${ }^{123}$ The Tribunal found that environmental protection measures were necessary for the modernisation, and so were fully integrated into the project and its costs, on the basis of the principles of sustainable development and prevention (thus burdening Belgium). However, the Tribunal mitigated this finding: where measures exceeded what was necessary to balance the environmental impacts of the railway's operation, and conferred some benefit to the Netherlands, the Netherlands was required to contribute a sum proportionate to that benefit.

The treaty underlying Pulp Mills (Category 3) allowed for a greater exploration of environmental norms: concluded in 1975, it provided for the protection of the marine environment, while maintaining a strong developmental focus. Environmental principles permeate the judgment. The Court held that Article 41, which required parties to protect and preserve the aquatic environment, reflected the prohibition against transboundary harm, ${ }^{124}$ and necessitated a "certain level of vigilance in [the rules'] enforcement and the exercise of administrative control". ${ }^{125}$ Further, as noted above, the Court found that the notification scheme incorporated the principle of prevention, and that EIAS were compulsory under customary international law, as a component of due diligence. On the other hand, the Court tempered this progressive and novel finding, and declined to substantiate what minimum requirements an EIA ought to possess for this obligation to be satisfied. Narrowing the broad finding to the present facts, the Court concluded that - despite Argentina's reliance on several instruments - no external law binding on the parties could provide guidance; rather, it was for each State to determine the content in its domestic legislation. This was an avoidable conclusion: as Fitzmaurice comments, the Court's appraisal of the obligation was "less onerous than obligations imposed by multilateral conventions", ${ }^{126}$ which largely require public consultation. Accordingly, customary law might impose certain obligations in EIAs; however, the Court's failure to survey State practice meant that it could merely

\footnotetext{
123 Iron Rhine, [74].

124 See Pulp Mills (Merits), [193]-[197].

125 Ibid., [197].

126 Fitzmaurice, supra note 24, at 372.
} 
assert a de minimis standard. ${ }^{127}$ Additionally, the Court rejected the argument that the precautionary approach shifted the burden of proof to Uruguay, requiring it to establish compliance. ${ }^{128}$ Ultimately, both parties agreed on the obligation to conduct an EIA, and Uruguay had, in fact, conducted one, pursuant to its domestic legislation; ${ }^{129}$ rather, it was only the sufficiency of that EIA that was in dispute. By not articulating a minimum standard, the Court did not engage with the issues in dispute: indeed, it ultimately found no breach of Article 41.

Finally, the South China Sea Arbitration (Category 4) demonstrates an expansive use of environmental norms. The Tribunal concluded that there was a positive duty to prevent, or at least mitigate, significant harm, relying on statements in Nuclear Weapons, Indus Waters, and Iron Rhine. Similarly, it cited IT LOS' 2015 SRFC Advisory Opinion ${ }^{130}$ in finding that States' obligation to prevent environmental harm pursuant to UNCLOS Article 194(5) connoted due diligence, requiring the adoption of appropriate measures and subsequent vigilance. It found that the Convention on International Trade in Endangered Species of Wild Fauna and Flora ('CiTEs') ${ }^{131}$ formed part of general international law on account of its near-universal adherence, and so informed UNCLOS Articles 192 and 194(5). The Tribunal further drew on the Convention on Biological Diversity ('СBD' $)^{132}$ and Cites to inform the breadth of the term 'ecosystem' under Article 194(5), ultimately adopting the expansive definition articulated in CBD Article 2. Taken together, these provisions imposed a due diligence obligation, preventing the harvesting of species considered at risk of extinction. China, by tolerating and protecting harvesting, had breached this obligation, despite adopting regulations to the contrary. ${ }^{133}$ The impact of the underlying treaty category on the use of norms is evident by comparing Pulp Mills (Category 3): the applicable treaty in that case similarly imposed an obligation "to protect and preserve" the aquatic environment; however, as above, the Court there limited the environmental norms invoked under that provision.

127 See Stefan Talmon, "Determining Customary International Law: The ICJ's Methodology between Induction, Deduction and Assertion", 26(2) The European Journal of International Law (2015), 417, 434-440.

128 Pulp Mills (Merits), [164].

129 Ibid., [203].

130 Request for an Advisory Opinion Submitted by the Sub-Regional Fisheries Commission $(S R F C)$ (Advisory Opinion) (ITLOS, 2 April 2015).

131 (Opened for signature 3 March 1973, entered into force 1 July 1975) 993 UNTS 243.

132 (Opened for signature 22 May 1992, entered into force 29 December 1993) 1760 UNTS 79.

133 South China Sea Arbitration, [964]-[965]. 
It ought to be noted that these differences between categories may also result from aspects inherent to the treaty, not merely its relationship with environmental law. Kolb, for example, argues that the more a treaty provision is targeted at protecting the public good, the more likely it is to attract an evolutive interpretation. ${ }^{134}$ Similarly, where the treaty is attached to a specific project or relationship, tribunals articulate obligations with greater precision of substance, and their potential for alteration diminishes over time. On the other hand, 'constitutional' treaties, such as UNCLOs, confer broad, durable rights without specific content, such that modern legal developments are clearly encompassed by the treaty's purpose, and fit easily within the wording used. However, at the very least, the intertemporal explanation posited here serves to account for differences in the judicial treatment of treaties within Categories 1-3.

Similarly, differences in the effect of norms on a dispute may be explained by factors inherent to the norm invoked. Material difficulties arise when elucidating the content of, or applying, norms that are vague in nature, as a greater contribution is required of the interpreter. ${ }^{135}$ Sustainable development and the precautionary approach cause issues in this arena, as they rely upon State policy by their very nature. Sustainable development lacks a norm-creating character, ${ }^{136}$ and cannot be applied as a standard ipso facto ${ }^{137}$ in the cases surveyed in which it was raised, it merely provided an expression of the balance otherwise inherent in the relevant treaty, ${ }^{138}$ or had little to no effect. ${ }^{139}$ Similarly, the content of the precautionary 'approach' is unclear, as are the

134 Robert Kolb, Interprétation et création du droit international (2006), 202-203.

135 Géraud de Lassus Saint-Geniès, "Les piliers économique et environnemental du développement durable: conciliation ou soutien mutuel? L'éclairage apporté par la Cour internationale de Justice dans l'Affaire des Usines de pâte à papier sur le fleuve Uruguay (Argentine c Uruguay)", 48 Annuaire canadien de droit international (2010), 151, 151.

136 Vaughan Lowe, "Sustainable Development and Unsustainable Arguments", in A. Boyle and D. Freestone (eds.), International Law and Sustainable Development: Past Achievements and Future Challenges (1999), 25.

137 Birnie and Boyle have commented: "it is difficult to see an international court reviewing national action and concluding that it falls short of a standard of 'sustainable development": Patricia Birnie and Alan Boyle, International Law and the Environment (2nd edition, 2002), 95 .

138 See, e.g., Pulp Mills (Merits), [75]-[77]; Gabčikovo-Nagymaros, [140].

139 See, e.g., Indus Waters (Partial Award), [449], where it was listed alongside a number of environmental principles. See also Iron Rhine, where it was used to justify the finding that the Netherlands was required to contribute costs to the extent of any benefit it received from its environmental measures: in that case, the concept of balance appears to have been relevant, rather than any application of the principle of sustainable development itself. 
circumstances in which it may be breached. Of the cases in this study, this approach appears only in the Advisory Opinion on the Area, being rejected as inapplicable by tribunals in Indus Waters and Pulp Mills. Here, however, the Chamber merely suggested that the approach should be taken by the parties. ${ }^{140}$ Indeed, even where the precautionary approach is found within a treaty, tribunals avoid drawing in external articulations of the norm: in the wT proceedings in Beef Hormones, ${ }^{141}$ for example, the Appellate Body - despite finding that the relevant provision incorporated the approach - expressly avoided deciding on the approach's legal status, as it could not override the express provisions or the application of general rules of treaty interpretation. ${ }^{142}$ However, if the approach had been deemed customary, assumedly vCLT Article 31(3)(c) - a usual principle of treaty interpretation - would have rendered it relevant.

\subsubsection{The Breadth and Content of the Norm Articulated}

Conterminous with the effect of environmental norms is the breadth of their articulation within each case. The above analysis indicates this tendency: while the Court in Pulp Mills (Category 3) articulated an obligation to undertake an EIA without further expanding on the specific conduct required, the Tribunal in the South China Sea Arbitration (Category 4) set out broad obligations to take positive steps to avoid harm.

However, there are four further factors that affect the breadth of the norm articulated.

First is the breadth of the treaty obligation founding the interpretation. The tribunals in the South China Sea Arbitration and Pulp Mills found that the treaty obligation to "protect and preserve" constituted the foundation of a number of other environmental norms. This term thus constitutes a 'framework principle', which can incorporate other environmental norms according to the dispute, and, in turn, allows more contentious norms to be attached. IT LOS, in its Advisory Opinion on the Area, for example, viewed the precautionary approach as an aspect of due diligence: ${ }^{143}$ although the former's content and status in general international law is controversial, ${ }^{144}$ the latter - an accepted understanding of the obligation "to protect and preserve" - offered a convenient stepping-stone. In that case, the Chamber's earlier finding that

\footnotetext{
140 Advisory Opinion on the Area, [131].

141 Appellate Body Report, European Communities - Measures Concerning Meat and Meat Products (Hormones) WT/DS26/AB/R; WT/DS48/AB/R (16 January 1998).

142 Ibid., [123]-[124].

143 Advisory Opinion on the Area, [121]-[135].

144 Pierre-Marie Dupuy and Jorge Viñuales, International Environmental Law (2nd edition, 2018), 70.
} 
Article 139 created an obligation of due diligence meant that this attribution embedded the precautionary approach within the UNCLOS regime, ${ }^{145}$ in parallel with the Chamber's extension of the approach in the Nodules Regulations and Sulphides Regulations to the UNCLOS regime more broadly. Articulating more controversial concepts as merely elements of established norms - being far more palatable than attempting to justify them as customary in and of themselves - is an approach facilitated by broad treaty terms. However, as exemplified by the differing uses of the framework principle in the South China Sea Arbitration and Pulp Mills outlined above, the breadth of the imported norms largely depends on the underlying treaty's relationship with environmental law.

A second factor impacting the breadth of the norm articulated is whether the parties in fact agree that the particular norm is applicable. In Indus Waters (Category 1), for example, India concurred that Pakistan ought to receive a minimum flow, ${ }^{146}$ such that the invocation of a number of broad norms in the Partial Award had no impact on the parties' situation. When India disagreed on the application of the norms - vis-à-vis the determination of the level of minimum flow - the Tribunal reverted to a far narrower approach. ${ }^{147}$ Similarly, the ICJ's progressive finding in Pulp Mills (Category 3) that EIAs were required by general international law was acceptable given that Uruguay had already conducted an EIA:148 the identification of a customary obligation did not retroactively place Uruguay in breach.

Third, where there is an instrument related to the treaty being interpreted that shares the same parties, the articulations contained in the secondary instrument are often transplanted across, facilitating the substantiation of broader norms in the primary instruments. This is notably seen in ITLOs' Advisory Opinion on the Area, ${ }^{149}$ in which the Chamber extended the precautionary approach's articulation in the Nodules and Sulphides Regulations, to the broader UNCLOS regime: the complete overlap in parties assisted in legitimising the imposition of this norm.

Finally, tribunals' effective enforcement of environmental norms appears to rely on the development of environmental principles in tribunals generally.

\footnotetext{
145 See Duncan French, "From the Depths: Rich Pickings of Principles of Sustainable Development and General International Law on the Ocean Floor - the Seabed Disputes Chamber's 2011 Advisory Opinion", 26 The International Journal of Marine and Coastal Law (2011), 525, 547 .

146 Indus Waters (Partial Award), [455].

147 Indus Waters (Final Award), [112].

148 Pulp Mills (Merits), [203].

149 Advisory Opinion on the Area, [121]-[135].
} 
While the Court's labelling of EIAs as custom in Pulp Mills had no effect there, this characterisation - and its characterisation of due diligence more generally - resulted in the imposition of EIAs as a customary norm in later cases. ${ }^{150}$ The development of environmental law in ITLOS' provisional measures cases is emblematic of this tendency. In Southern Bluefin Tuna, ${ }^{151}$ ITLOS did not explicitly rely on the precautionary approach, although implied its possible relevance. However, in Ghana/Côte d'voire, ${ }^{152}$ it cited this earlier comment, and relied upon it to directly incorporate the approach. ${ }^{153}$ The more expansive these prior decisions, the more expansive an obligation is identified; conversely, where only a restricted norm is identified - such as the Tribunal in Iron Rhine's articulation of the principle of prevention - the more narrow its subsequent articulation (as in Indus Waters). ${ }^{154}$ The considerable impact of judicial decisions in the environmental law regime has been noted; ${ }^{155}$ the development of the law by international tribunals, as judicial bodies, thus has a legitimising effect. ${ }^{156}$

\subsubsection{The Basis of the Norm Articulated}

As noted above, tribunals indicate a preference for relying on statements in prior jurisprudence as the 'source' for an environmental norm's customary nature. This practice occurs even when not required: the Tribunal in the South China Sea Arbitration, for example, relied on statements in Nuclear Weapons, Indus Waters, and Iron Rhine, in addition to the СвD and CITES, despite its (acknowledged) ability to directly apply those treaties, through application of UNCLOS Article 237. ${ }^{157}$

\footnotetext{
150 See Indus Waters (Partial Award), [448]-[451]; South China Sea Arbitration, [948]; Advisory Opinion on the Area, [147]-[150].

151 Southern Bluefin Tuna (New Zealand v. Japan) (Provisional Measures) (1999) 38 ILM 1624.

152 Delimitation of the Maritime Boundary in the Atlantic Ocean (Ghana/Côte d'Ivoire), Judgment, ITLOS Reports 2017, p. 4.

153 See Tim Stephens, International Courts and Environmental Protection (2009), 224.

154 Indus Waters (Partial Award), [451]: "the duty to prevent, or at least mitigate significant harm", citing Iron Rhine, [59]. Cf. Stockholm Declaration, Principle 21 "States have ... the responsibility to ensure that activities within their jurisdiction or control do not cause damage to the environment of other States or of areas beyond the limits of national jurisdiction".

155 Markus Vordemayer, "Gardening the Great Transformation: The Anthropocene Concept's Impact on International Environmental Law Doctrine", 25 Yearbook of International Environmental Law (2015), 79, 110.

156 Stephens, supra note 153, at 247; Christina Voigt, "International Courts and the Environment", in C. Voigt (ed.), International Judicial Practice on the Environment (2019), 17.

157 South China Sea Arbitration, [942].
} 
Tribunals also eschew external sources in determining an external norm's customary nature where the underlying treaty obligation connotes an environmental norm itself. The tribunals in the South China Sea Arbitration and Pulp Mills both imported broad norms into the obligation to "protect and preserve", without exploring the customary bases on which their evolutive expansions relied. The ICJ in Gabčikovo-Nagymaros similarly held that the duty to protect water quality incorporated present environmental standards, including the prevention of harm, without reference to practice. ${ }^{158}$

Furthermore, tribunals rely on international instruments primarily as a source for norms' basic definitions, rather than their content per se: several cases cite the Rio Declaration for its expression of the precautionary approach, ${ }^{159}$ but fail to engage further with its content. Instruments are also used to substantiate evolutive definitions, as exemplified in the South China Sea Arbitration and Shrimp-Turtle, both of which involved updating a term 'ecosystem' and 'exhaustible natural resources', respectively - in accordance with current practice. The tribunals in each matter relied largely on environmental treaties - CITES and the CBD - with Shrimp-Turtle relying on UNCLOS as an additional source. ${ }^{160}$

Final Thoughts

Overall, modern courts and tribunals, to varying degrees, are willing to adopt environmental norms in their findings, using a range of interpretative approaches to justify their invocation, each to various effect. These invocations, however, ultimately depend on the underlying instrument, and its relationship to both environmental law and the evolution of its terms. Whether a tribunal will allow an environmental claim, which interpretative devices it will use, and the likely extent of its engagement with norms are broadly predictable according to this model.

With regard to the problem originally articulated - that the lack of recent environmental norms in older treaties, and the lack of enforcement mechanisms in contemporary ones, hamper States' ability to litigate issues of environmental law - this determination is of great significance. This article, in demonstrating when and how environmental norms are effectively used in litigation concerning historic treaties, provides direct guidance to States.

$15^{8}$ Gabčíkovo-Nagymaros, [112].

159 Iron Rhine, [58]-[59]; Advisory Opinion on the Area, [127].

16o South China Sea Arbitration, [941]-[956]; Shrimp-Turtle, [23]-[25]. 
In particular, where States interested in pursuing an environmental claim can choose between treaties as a basis for jurisdiction, the above discussion indicates that tribunals are more willing to incorporate and use expansive, contemporary norms in Category 3 and 4 treaties, than in those in Category 1. In any case, the results of this article highlight the central role tribunals play in developing and enforcing international environmental law: in the absence of new multilateral treaty regimes, these institutions provide the ideal fora for progressive legal change, and it is imperative States use them for this purpose. 